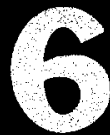




\section{DISORDER IN OUR TIME}

\section{ANARCHISM, VIOLENCE} AND CIVIL DISORDER

Paul W. Blackstock

\section{HUMAN NATURE AND} INTERNATIONAL COMMUNITY, II

Seth Tillman

FEAR IN OUR TIME

Other Voices

\section{TOWARD A CHRISTIAN THEOLOGY OF CONTEMPORARY JUDAISM}

Monika Hellwig 